FILIP PRĘGOWSKI

\title{
W PRZESTRZENI WYMIANY. OBRAZY JACKA GOLDSTEINA I FOTOGRAFIE OLIVERA WASOWA
}

W roku 1986 w tekście Signs Taken For Wonders, opublikowanym w magazynie „Art in America”, Hal Foster zwrócił uwagę na zwrot w kierunku malarstwa, który dokonał się wówczas z udziałem wielu amerykańskich artystów, znanych wcześniej z działań o charakterze konceptualnym, tworzących performance, fotografię czy sztukę wideo. Amerykańskiego krytyka i historyka sztuki nie interesowała jednak rehabilitacja malarstwa i powrót do jego mitologii, lecz twórczość, która podejmowała ironiczną grę z tradycją i podważała instytucjonalnie usankcjonowane kanony modernizmu ${ }^{1}$.

Wśród wymienionych w tekście Fostera artystów znaleźli się między innymi Jack Goldstein i Oliver Wasow ${ }^{2}$, których twórczość, realizowana w latach 80. odpowiednio w medium malarstwa i fotografii, stanowi szczególnie interesujący materiał porównawczy. W obu wypadkach (jak postaram się pokazać, ściśle ze sobą powiązanych) aktualne pozostaje też pytanie, które postawił krytyk - pytanie o logikę i dynamikę przekraczania granic pomiędzy poszczególnymi dyscyplinami artystycznymi, które stało się kluczową cechą sztuki końca XX wieku (a które ilustruje malarska przemiana Jacka Goldsteina w latach 80. czy malarski charakter fotografii Olivera Wasowa z tego okresu). Na przykładzie prac obu artystów przedstawię okoliczności, w jakich w malarstwie i fotografii dochodzi nie tylko do podważenia specyfiki i odrębności medium, ale także do wzajemnej wymiany właściwych

${ }^{1}$ H. Foster, Signs Taken For Wonders, „Art in America” 1986, 74(6). Korzystałem z przedruku w: Painting. Documents of Contemporary Art, red. T.R. Myers, London, Cambridge 2011, s. 47-57.

${ }^{2}$ Jack Goldstein (1945-2003) urodził się w Kanadzie, mieszkał i pracował w Los Angeles i w Nowym Jorku, ukończył California Institute of the Arts w pracowni Johna Baldessari. Oliver Wasow ( ${ }^{*} 1960$ ) mieszka i pracuje w Nowym Jorku. Ukończył Hunter College w Nowym Jorku i Transart Institute w Krems w Austrii. 
obu dyscyplinom strategii obrazowania. Zjawisko to, wpisując się w szerokie spektrum nurtów sztuki lat 70. i 80. ${ }^{3}$ ubiegłego wieku, znajduje także swoje odzwierciedlenie w dyskursie o kondycji medium, w którym wiodącą rolę odegrały analizy Rosalind Krauss. Zamierzam zreferować historyczne tło zmian, w wyniku których konieczne było porzucenie idei autonomii i specyfiki medium, a także wskazać, odnosząc się do rozważań Douglasa Crimpa i Rosalind Krauss, że zmiany te dotyczyły także procesu kształtowania się semantycznego obszaru twórczości Goldsteina i Wasowa. W tej perspektywie prace amerykańskich artystów, poddając dekonstrukcji pojęcia medium czy reprezentacji, wpisują się w nurt krytyki własnych dyscyplin artystycznych i narosłych wokół nich mitologii. Z drugiej jednak strony, powstając w związku z rozwojem technologii transmisji obrazu lat 80., zdradzają one fascynację estetyką spektaklu (rozumianą zgodnie z koncepcją Guya Deborda). Jeśli zatem uznać, że prace te poddane są wyłącznie kategoriom estetyzacji rzeczywistości i tworzą, jak pisał Debord, tautologiczny spektakl, którego „środki są tożsame [...] z celem”, i który „nie zmierza do niczego poza sobą samym"4, wówczas ich krytyczny wymiar staje pod znakiem zapytania. Ta podstawowa sprzeczność, znajdująca wyraz między innymi w interpretacjach sztuki lat 80 . autorstwa Hala Fostera, odnosi się do dzieł wielu artystów tego okresu. Kształtuje ona także niepewny status obrazów i fotografii Goldsteina oraz Wasowa, sprawiając, że wskazanie ich roli - pomiędzy narzędziem krytyki a fetyszystycznym towarem - okazuje się niezwykle trudne.

\section{THE PICTURES GENERATION}

Zarówno Jack Goldstein, jak i Oliver Wasow wymieniani są wśród artystów współtworzących niejednorodną stylistycznie, lecz posługującą się podobnymi koncepcjami, pokoleniową grupę The Pictures Generation. Swoją nazwę zawdzięcza ona zorganizowanej przez Douglasa Crimpa wystawie

${ }^{3}$ Rosalind Krauss, pisząc o sztuce lat 70., charakteryzowała jej różnorodność w kategoriach rozproszenia (przywołując termin, będący tytułem książki Alana Sondheima Post-Movement Art in America), odróżniając ją od sztuki poprzednich dekad, dającej się opisać jednym syntetycznym pojęciem, jak ekspresjonizm abstrakcyjny czy minimalizm. Zob. R.E. Krauss, Notatki o indeksie. Część 1, w: Oryginalność awangardy i inne mity modernistyczne, tłum. M. Szuba, Gdańsk 2011, s. 201.

${ }^{4}$ G. Debord, Społeczeństwo spektaklu oraz Rozważania o społeczeństwie spektaklu, red. E. Staśkiewicz, tłum. M. Kwaterko, Warszawa 2006, s. 36, 37. 
„Pictures” w galerii Artists Space w Nowym Jorku w roku 1977, w której prócz Goldsteina brali udział Troy Brauntuch, Sherrie Levine, Robert Longo i Philip Smith ${ }^{5}$. Wiele lat późniejsza wystawa „The Pictures Generation, 1974-1984", która miała miejsce w Metropolitan Museum of Art w roku $2009^{6}$, przyczyniła się do znacznego poszerzenia grupy artystów kojarzonych $z$ ruchem: $z$ wyjątkiem Philipa Smitha, prócz dzieł wymienionych twórców prezentowane były na niej między innymi prace Barbary Kruger, Thomasa Lawsona, Roberta Longo, Richarda Prince'a, Davida Salle, Cindy Sherman, Jamesa Wellinga, a także Johna Baldessari, którego status legendarnego artysty i znanego pedagoga California Institute of the Arts uczynił go w tym kręgu postacią centralną.

Do artystycznych strategii wykorzystywanych przez przedstawicieli The Pictures Generation należą przede wszystkim techniki zawłaszczania (appropriation), dokonujące odwrócenia znaczenia i nadające krytyczny wydźwięk dominującym w kulturze popularnej kodom i dyskursom bądź też poddające krytycznemu namysłowi status oryginału i kopii w sztuce. Artyści ci wykorzystywali gotowe wizerunki zapożyczone z mediów, reprodukowali prace innych twórców, posługiwali się cytatami i parafrazami. Ich twórczość powstawała w opozycji do modernistycznego paradygmatu autonomii sztuki i suwerenności poszczególnych jej dyscyplin (którego emanacją na przełomie lat 70 . i 80. była estetyka neoekspresjonizmu| ${ }^{7}$, chętnie korzystając $z$ technik dających szczególne możliwości reprodukcji i powielania, takich jak fotografia, wideo i film.

5 „Pictures”, Artists Space, Nowy Jork, 24 września - 29 października 1977, kurator: Douglas Crimp. Zob. D. Crimp, Pictures, „X-tra”, jesień 2005, 8(1), s. 17 (tekst jest przedrukiem wstępu do katalogu wystawy).

6 „The Pictures Generation, 1974-1984”, Metropolitan Museum of Art, 21 kwietnia 2 sierpnia 2009, kurator: Douglas Eklund.

7 O neoekspresjonizmie jako chybionym projekcie reanimowania Benjaminowskiej aury dzieła sztuki wspominał autor wystawy „Pictures” - Douglas Crimp. W tekście The Photographic Activity of Postmodernism zwracał między innymi uwage na wypowiedzi Barbary Rose, jednej z czołowych propagatorek neoekspresjonistycznego malarstwa amerykańskiego, autorki wystawy "American Painting: The Eighties” w Grey Art Gallery w Nowym Jorku w roku 1979. Crimp piętnował wyznawaną przez Rose wiarę w malarstwo jako sztukę transcendencji, łączącą indywidualną ekspresję z uniwersalizmem treści, uważając to za anachronizm i zarzucając krytyczce nierozumienie roli fotografii we współczesnej sztuce. D. Crimp, The Photographic Activity of Postmodernism, „October" 1980, 15, s. 96. Zob. też: idem, The End of Painting, „October” 1981, 16, s. 69-76. Oba teksty znalazły się także w zbiorze esejów Crimpa On the Museum's Ruins, Cambridge, London 1993, s. 84-108 i 108-126. 
Powstające w pierwszej połowie lat 80. malarskie dzieła Jacka Goldsteina i fotografie Olivera Wasowa wydają się zjawiskiem z jednej strony typowym dla The Pictures Generation, z drugiej zaś - zachowującym swoją odrębność. Na najbardziej podstawowym poziomie odbioru objawia się ona w systematyczności i cykliczności doboru tematów. Obrazy Jacka Goldsteina przedstawiają zjawiska atmosferyczne i geologiczne, takie jak gwałtowne wyładowania elektryczne (il. 1), widoki nocnego nieba i erupcje wulkanów, nocne panoramy miast, z których w kierunku nieba padają silne snopy światła (il. 2, 5), czy radioteleskopowe widoki galaktyk i odległych obiektów kosmicznych (il. 3, 4). Punktem wyjścia dla obrazów były wykorzystane przez Goldsteina zdjęcia wykonane przez obserwatoria astronomiczne lub reporterskie fotografie $z$ okresu drugiej wojny światowej ${ }^{8}$. Prace zrealizowane są w oszczędnej kolorystyce, ograniczonej do zestawionych w silne kontrasty barw podstawowych.

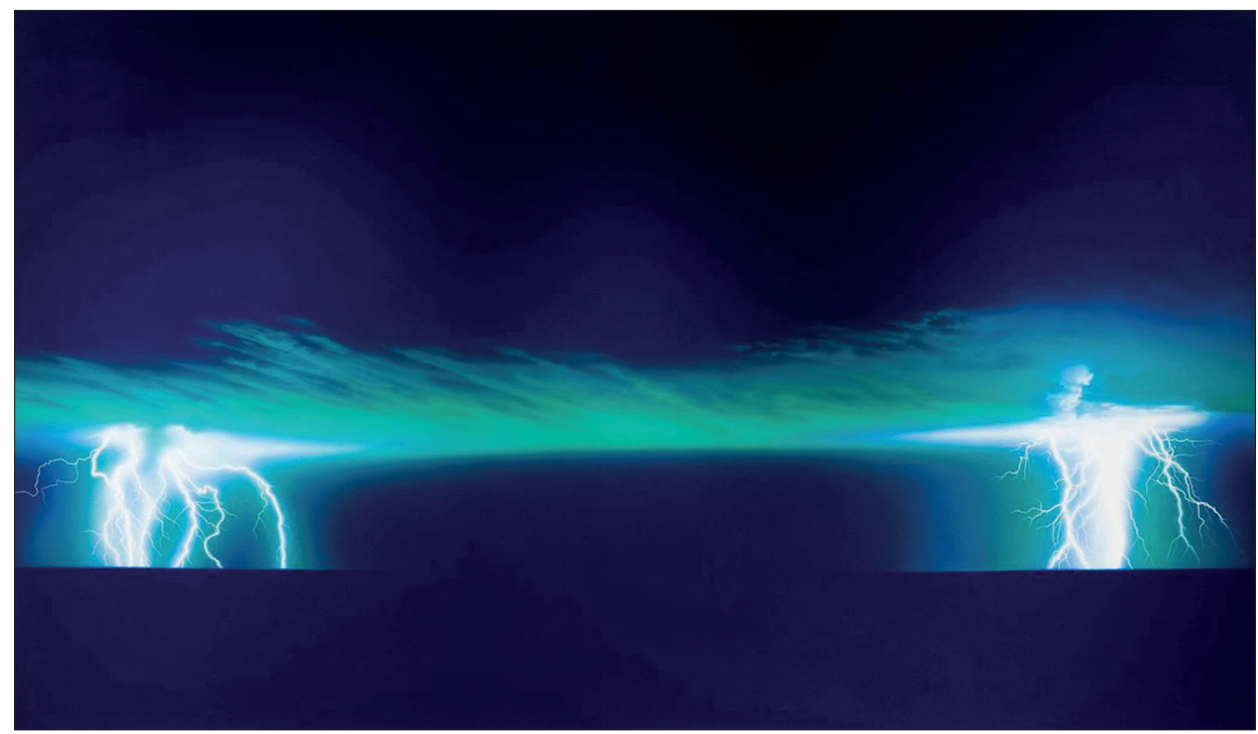

1. Jack Goldstein, Untitled, 1983, akryl na płótnie, dzięki uprzejmości The Estate of Jack Goldstein

${ }^{8}$ Część prac z cyklu Goldsteina powstała na podstawie zdjęć bombardowanych w czasie drugiej wojny światowej Drezna i Moskwy, w tym drugim wypadku autorstwa amerykańskiej fotoreporterki Margaret Bourke-White (il. 5). Zob. J.R. Wolin, Jack Goldstein x 10.000, „Time Out New York" [online], <https://www.timeout.com/newyork/art/jack-goldstein-x-10-000> [dostęp: 1 lutego 2017]. Artykuł dotyczy wystawy „Jack Goldstein x 10.000”, Jewish Museum, Nowy Jork, 10 maja - 29 września 2013, kurator: Philipp Kaiser. 


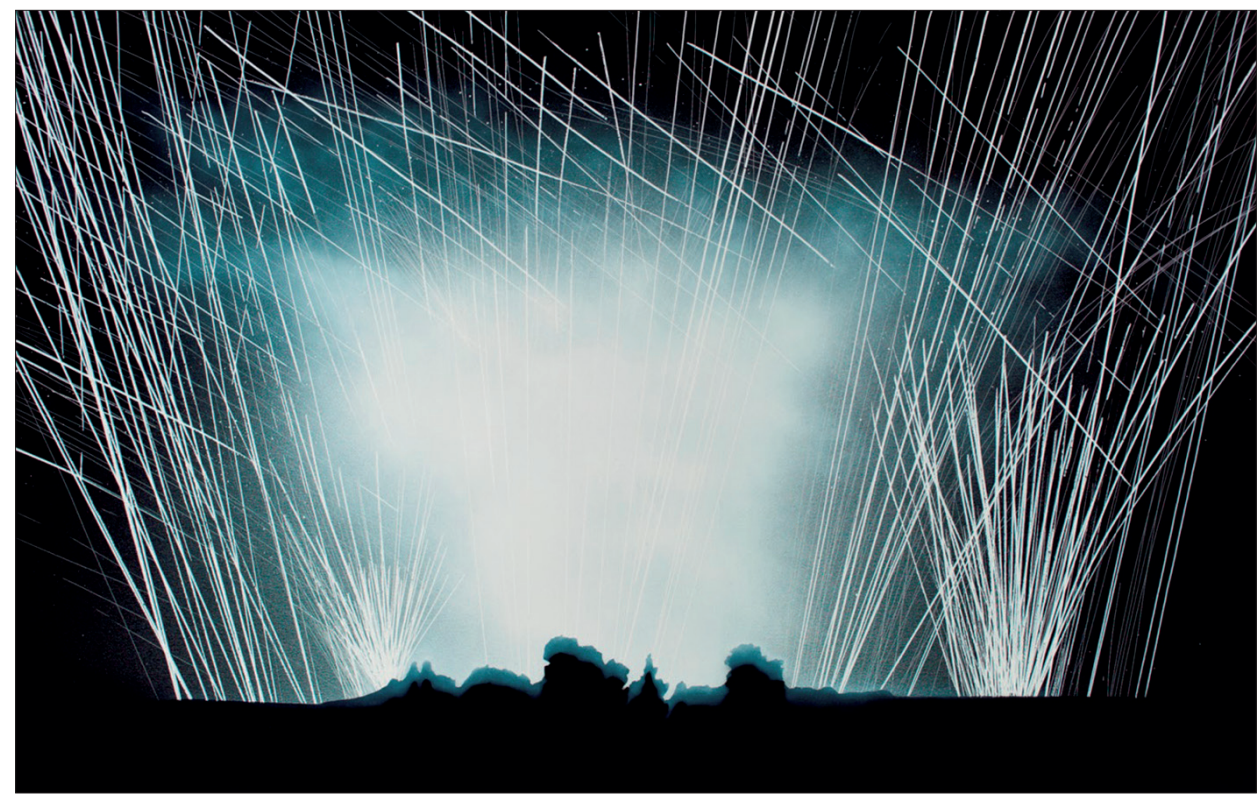

2. Jack Goldstein, Untitled, 1981, akryl na płótnie, dzięki uprzejmości The Estate of Jack Goldstein

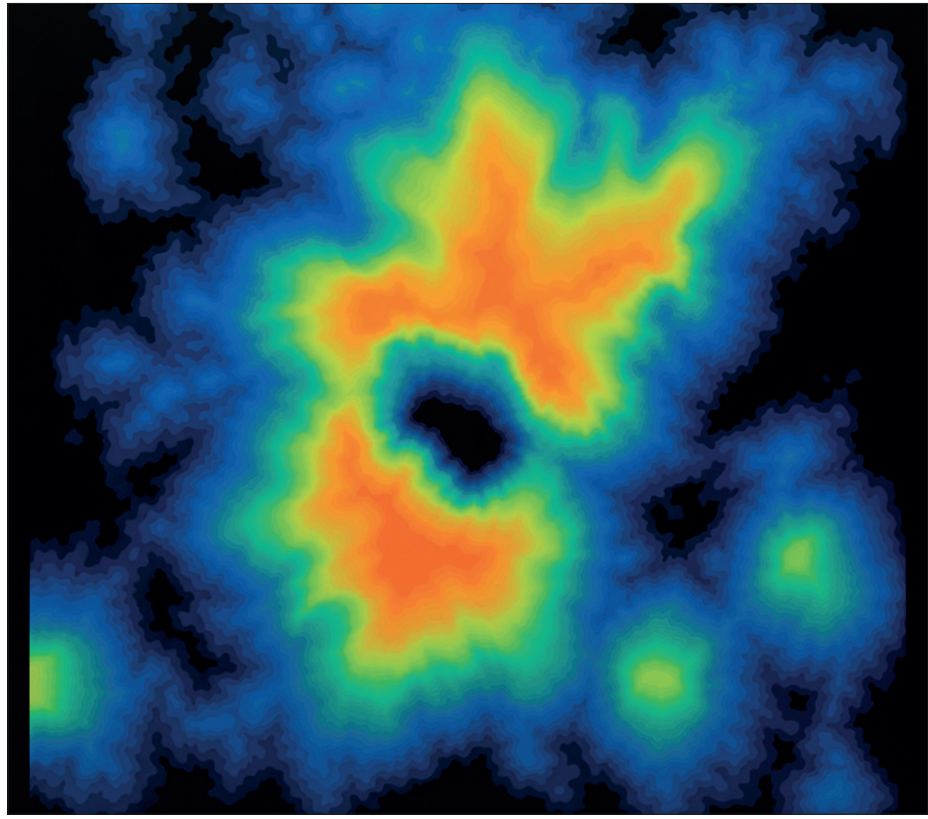

3. Jack Goldstein, Untitled, 1988, akryl na płótnie, dzięki uprzejmości The Estate of Jack Goldstein 


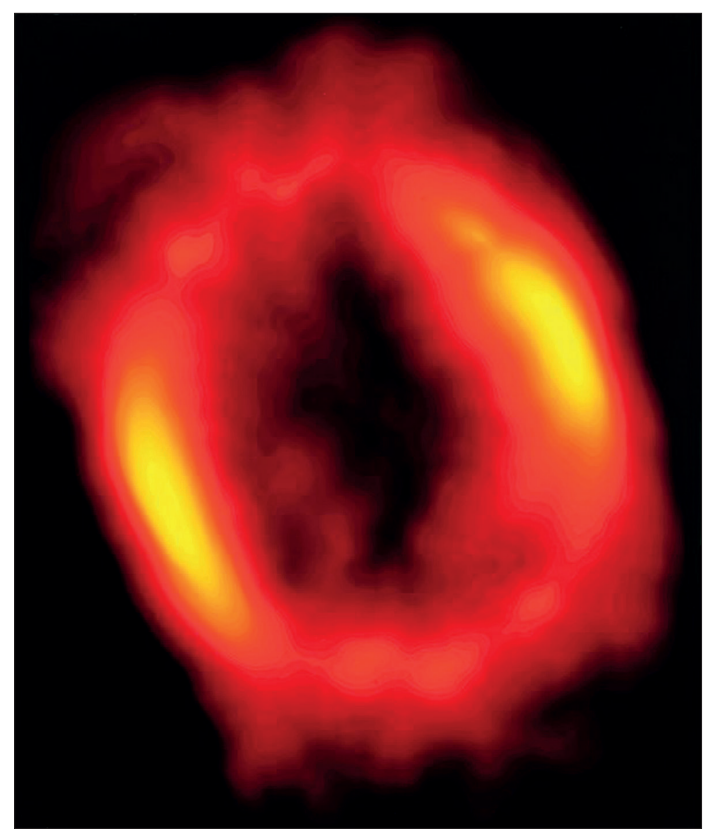

4. Jack Goldstein, Untitled, 1988, akryl na płótnie, dzięki uprzejmości The Estate of Jack Goldstein

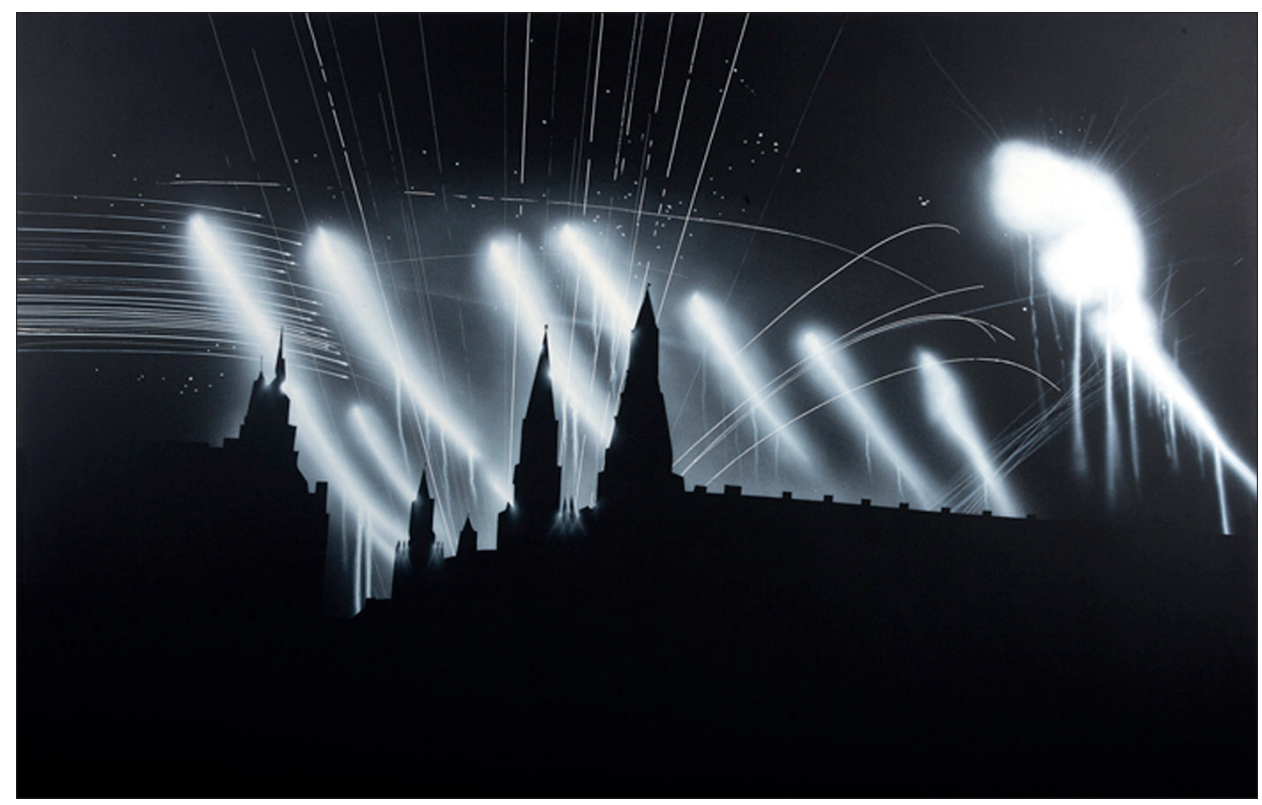

5. Jack Goldstein, Untitled, 1981, akryl na płótnie, dzięki uprzejmości The Estate of Jack Goldstein 
Ciemne lub całkiem czarne tła oraz pozbawiona efektów malarskich technika wykonania, przypominająca wielkoformatową, barwną fotografię, sprawiają, że wizualna atrakcyjność obrazów naznaczona jest także pewnym dystansem i chłodem. Prace Olivera Wasowa z cyklu Hover mogłyby w zasadzie uchodzić za kontynuację serii Goldsteina; prócz niezwykłych - naturalnych bądź sztucznych - efektów świetlnych na tle nieba (il. 9, 10) przedstawiają także niezidentyfikowane obiekty latające, przemykające ponad krajobrazem lub zawieszone w przestrzeni, jakby w oczekiwaniu na lądowanie (il. 6, 7, 8). Wasow korzystał $z$ gotowych fotografii; przekształcając je $z$ zastosowaniem technik fotomontażu i ręcznego retuszu w studio oraz ograniczając, podobnie jak Goldstein, gamę kolorystyczną do kontrastowo zestawianych barw podstawowych, nadał scenom widmowy charakter.

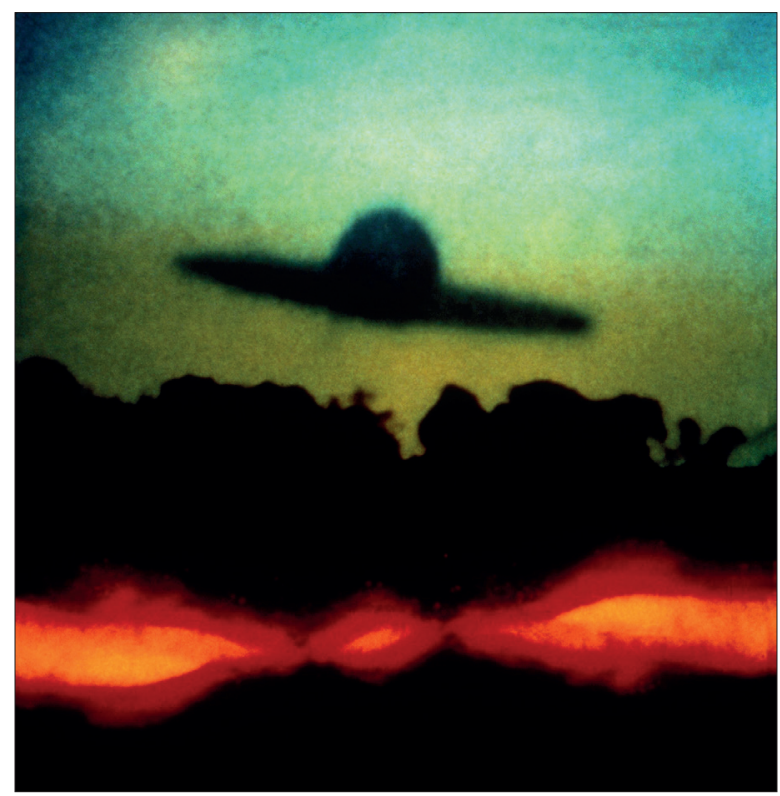

6. Oliver Wasow, Soft Landing, 1986, cibachrome, dzięki uprzejmości artysty

W obu przypadkach nasuwa się skojarzenie $z$ chłodną, zdystansowaną estetyzacją, jakiej Andy Warhol poddawał przekształcane w procesie serigrafii zdjęcia, gdzie pod barwnym, akrylowym „makijażem” kryje się - jak pisał Fredric Jameson - śmiertelne, czarno-białe podłoże fotograficznego negatywu’

9 F. Jameson, Postmodernizm, czyli logika kulturowa późnego kapitalizmu, tłum. M. Płaza, Kraków 2011, s. 10. 


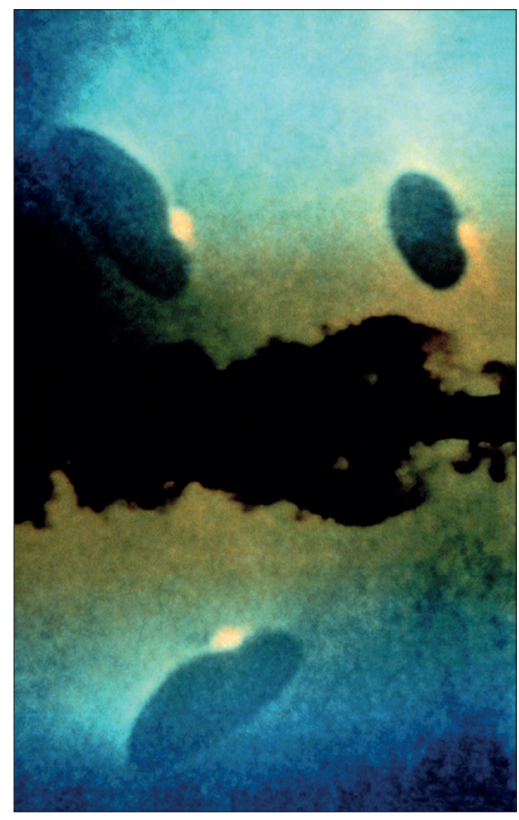

7. Oliver Wasow, Three discs, 1986, cibachrome, dzięki uprzejmości artysty

Tak właśnie prezentują się prace Goldsteina i Wasowa - zrodzone z krążących w ikonosferze wizerunków fotograficznych lub kadrów filmowych, zdradzają jednoczesną fascynację i neutralizujący dystans, podkreślony bezosobową techniką wykonania. $\mathrm{W}$ tym sensie wpisują się one, podobnie jak prace innych artystów The Pictures Generation stosujących strategię zawłaszczania, w pojawiający się w rozmaitych odniesieniach kryzys późnego kapitalizmu lat 80., którego początki Jameson lokował w przełomie lat 50. i 60. Kryzys ten lub poczucie końca ruchu modernizacyjnego, napędzającego minione stulecie, miał charakter zarówno ideologiczny, jak i estetyczny ${ }^{10}$, nadając kulturze tego okresu specyficzny rys ambiwalencji pomiędzy krytyką dominujących dyskursów i ideologii kapitalizmu a udziałem w niekończącym się cyklu komodyfikacji. Prace Goldsteina i Wasowa urzekają „lodowatą, rentgenowską elegancją" ${ }^{11}$, operując wyestetyzowanymi wizjami katastrofy lub fantazji science fiction, za którymi kryje się zarówno oczarowanie, jak i lęk. W tym miejscu warto dodać, że Fredric Jameson

10 Ibidem, s. 1.

${ }_{11}$ Ta charakterystyka, zaczerpnięta z analizy pracy Andy'ego Warhola Diamond Dust Shoes, ilustrującej opisane przez Jamesona postmodernistyczne wyparcie afektu, wskazuje na kilka dalszych - jak pisze amerykański krytyk kultury i socjolog - przykładów odrzucenia modernistycznych paradygmatów: odrzucenie dialektycznego modelu istoty i pozoru (bądź też oryginału i kopii), rezygnacja z freudowskiego modelu utajonego i widocznego, odejście od egzystencjalnego modelu autentyczności i nieautentyczności (bądź też metafizyki wnętrza podmiotu poddanego przemocy czynników zewnętrznych) i wreszcie porzucenie semiotycznej opozycji między znaczącym a znaczonym, która zatraca się w grze tekstualnej. Zob. Jameson, Postmodernizm, czyli logika kulturowa..., s. 12. 


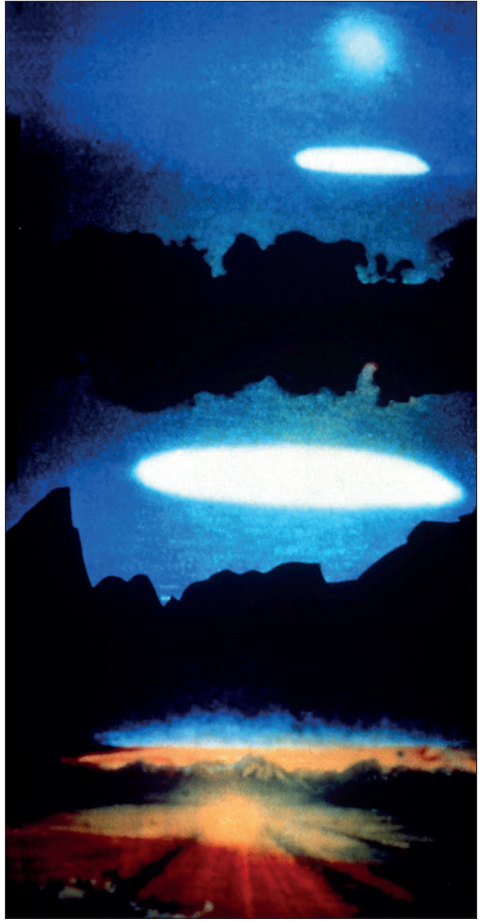

8. Oliver Wasow, Descending Lights, 1985, cibachrome, dzięki uprzejmości artysty

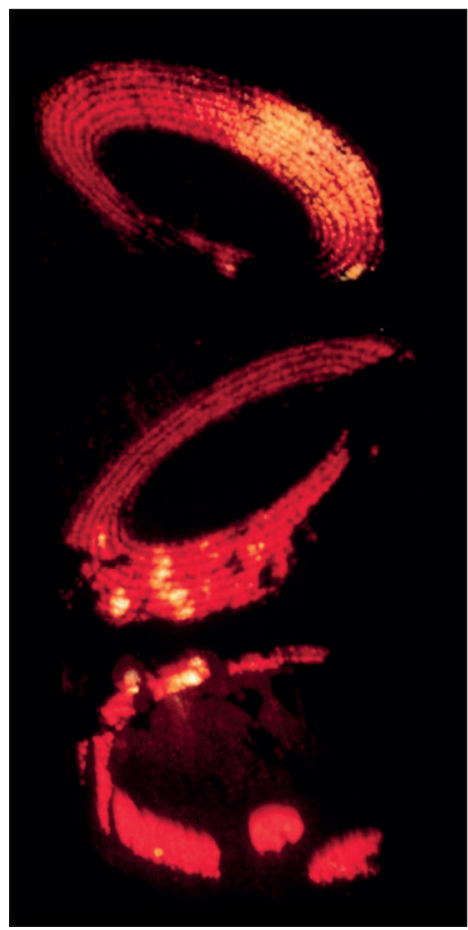

9. Oliver Wasow, Three Circles, 1985, cibachrome, dzięki uprzejmości artysty

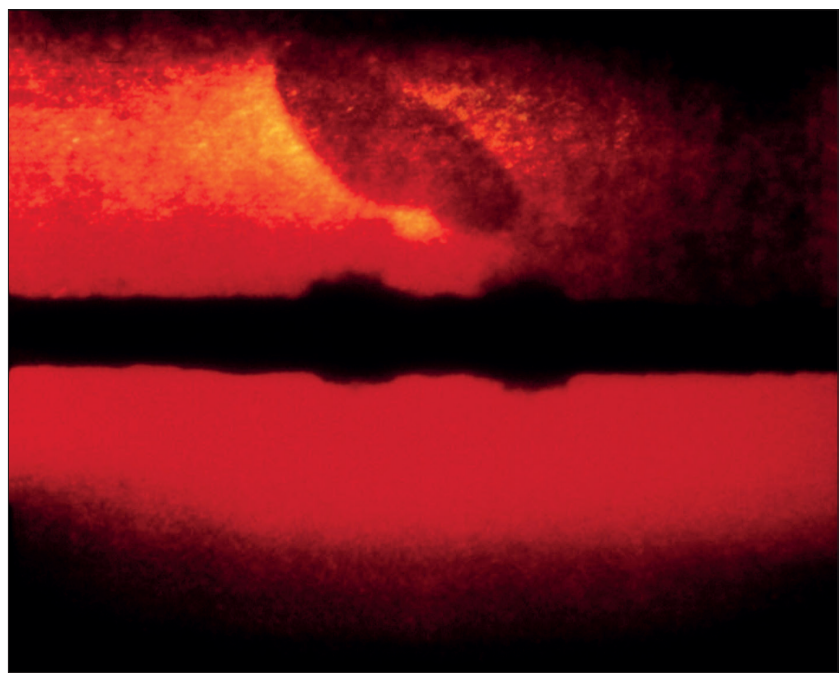

10. Oliver Wasow, One Disc, 1985, cibachrome, dzięki uprzejmości artysty 
dostrzegł związki „utopijnych kręgosłupowych pejzaży” Wasowa z zaświadczającą o społecznej i historycznej katastrofie prozą J.G. Ballarda ${ }^{12}$. Na uwagę szczególnie zasługuje ironiczne spostrzeżenie, że utrzymane w „halucynacyjnych barwach" fotografie przypominają płomienne zachody słońca nad Santa Monica, które swój efektowny wygląd zawdzięczają ogromnemu stężeniu chemicznych zanieczyszczeń w powietrzu.

\section{MEDIUM}

Dynamika relacji między obrazami Jacka Goldsteina a fotografiami Olivera Wasowa ściśle związana jest ze sposobem, w jaki w ich estetycznej przestrzeni zachodzi wymiana między cechami oraz strategiami wizualnymi malarstwa i fotografii. Zrozumienie tych relacji wymaga dwóch rzeczy. Po pierwsze, nakreślenia roli, jaką we współczesnej kulturze pełni fotografia, po drugie zaś - zdefiniowania samego pojęcia medium.

Jak pisała Rosalind Krauss w eseju Reinventing the Medium ${ }^{13}$, przemyślenie dominującej roli fotografii we współczesnej kulturze wizualnej wymagało nie tyle uwzględnienia historii i tradycji dyscypliny, ile potraktowania jej jako obiektu namysłu teoretycznego, w którym specyfika medium traci na znaczeniu. Sięgając do eseju Waltera Benjamina Dzieło sztuki w dobie reprodukcji technicznej z roku 1936, Krauss dokonała zwrotu w przeszłość, aby prześledzić drogę do kluczowej pozycji fotografii w sztuce lat 60 . Z jej punktu widzenia, obejmującego także wcześniejszą perspektywę Benjamina, zwrot z lat 60. był powtórzeniem konwergencji sztuki i fotografii, jaka nastąpiła w latach 20., na przykład w radzieckim fotomontażu, praktykach dadaistów czy sztuce surrealizmu ${ }^{14}$. Przywołując esej Benjamina, w którym fotografia jako obiekt teoretyczny zyskała siłę objaśnienia przyczyn transformacji następujących w sztuce w ogóle, nie tylko w obrębie własnej dyscypliny, wskazała na fundamentalną w tym kontekście kwestię: fotografia zarówno uczestniczyła w awangardowych przemianach sztuki, jak i je dokumentowała ${ }^{15}$. Znane słowa Benjamina, że „reprodukowane dzieło sztuki w coraz większym stopniu

12 Ibidem, s. 182.

13 R.E. Krauss, Reinventing the Medium, "Critical Inquiry”, zima 1999, 25(2), s. 289-305. Analizy Rosalind Krauss dotyczące kondycji medium we współczesnej sztuce referowała też Agnieszka Rejniak-Majewska: A. Rejniak-Majewska, „Kondycja postmedialna" i wynajdowanie medium według Rosalind Krauss, w: Sztuki w przestrzeni transmedialnej, red. T. Załuski, Łódź 2010, s. 42-52.

${ }^{14}$ A także artystów związanych z takimi awangardowymi środowiskami, jak Bauhaus.

15 Krauss, Reinventing the Medium, s. 294. 
staje się reprodukcją dzieła sztuki już w swym założeniu obliczonego na możliwość reprodukcji”16, badaczka podkreśliła uwagą, że fenomen reprodukcji stopniowo utożsamił akt percepcji i artystycznej kreacji z gestem fotograficznego ujmowania świata w kadr (kadrowania rzeczywistości) ${ }^{17}$.

W zjawisko to wpisuje się włączenie fotografii reporterskiej i dokumentalnej w obszar zainteresowań sztuki awangardowej, co miało być także gestem wymierzonym przeciw fotografii artystycznej (utożsamianej ze światem artystycznego subiektywizmu), ale pomogło również odkryć inspiracje w tym, co dotąd uznawane było za "nieartystyczne" ${ }^{18}$. Kluczowe dla tej przemiany są więc praktyki artystyczne i założenia teoretyczne, zgodnie z którymi odrzucono podziały definiujące poszczególne dyscypliny jako odrębne i specyficzne, dążąc do traktowania sztuki w ujęciu generalnym. Znakomitym tego przykładem może być wydana w roku 1925 przez wydawnictwo Bauhausu książka László Moholy-Nagya Malerei Fotografie Film ${ }^{19}$. Znaczenie tej rozprawy, dotyczącej nowych możliwości ekspresji, jakich dostarcza obraz fotograficzny i kinowy, oraz ich relacji z malarstwem polega nie tylko na tym, że przyznała fotografii absolutny prymat wśród sztuk wizualnych. Równie ważny jest fakt, że w materiale ilustracyjnym zestawione zostały fotogramy Moholy-Nagya i innych autorów - anonimowe, dokumentalne zdjęcia przyrody i zjawisk atmosferycznych, kadry z filmów i reprodukcje abstrakcyjnych obrazów artysty. Czarno-biała technika reprodukcji stała się narzędziem, dzięki któremu zrealizował się zamysł autora, aby przedstawić poszczególne media w dynamicznej relacji wzajemnej wymiany wizualnych parametrów ${ }^{20}$.

Powrót do awangardowej koncepcji zjednoczenia poszczególnych dyscyplin artystycznych nastąpił w sztuce lat 60 . Jednym z pierwszych powojennych przykładów tego rodzaju koncepcji mogłaby być wczesna praca typu combine Roberta Rauschenberga Rebus z roku 1955. Dzieło to, łączące elementy malarstwa, rysunku, wyciętych i pokolorowanych fragmentów gazet oraz fotografii, jest nie tylko przykładem zacierania granic między mediami, ale dzięki zamaszystej, ekspresjonistycznej formule partii malarskich może stanowić też rodzaj pomostu pomiędzy praktykami artystycznymi eksponującymi medium w służbie artystycznego gestu (jak ekspresjonizm abstrak-

${ }^{16}$ W. Benjamin, Dzieło sztuki w dobie reprodukcji technicznej, tłum. J. Sikorski, w: idem, Twórca jako wytwórca, wybór H. Orłowski, wstęp J. Kmita, Poznań 1975, s. 74-75.

${ }_{17}$ Krauss, Reinventing the Medium, s. 293.

18 Ibidem, s. 295.

19 L. Moholy-Nagy, Malerei Fotografie Film, München 1925; korzystałem z angielskiego przekładu: Painting Photography Film, tłum. J. Seligman, London 1969.

20 C. Armstrong, Painting Photography Painting, w: Painting Beyond Itself. The Medium in Post-Medium Condition, red. I. Graw, E. Lajer-Burcharth, Berlin 2016, s. 132-135. 
cyjny) a sztuką definiującą medium na nowo ${ }^{21}$. Ów „przejściowy” status prac z serii combines mogłyby również potwierdzić słowa Piotra Piotrowskiego (odnoszące się wprawdzie do sukcesu Rauschenberga na Biennale w Wenecji w roku 1964), że w oczach Amerykanów „łączył [on] elitaryzm z modernizmem, wolność z powszedniością, ulicę z muzeum", rezygnując w swoich odniesieniach do dadaistycznej klasyki z jej krytycznego charakteru na rzecz „optymistycznej afirmacji”22. Z naszego punktu widzenia ważniejsze wydaje się jednak to, że - jak pisała Carol Armstrong - Rebus wyznaczyło moment, w którym fotografia definitywnie wkroczyła w obszar malarstwa ${ }^{23}$. Wagę tego przykładu potwierdza dalsza droga twórcza Rauschenberga, który przechodził stopniowo od form produkcji, czyli artystycznie przetworzonych obiektów (combines, assemblages), do stosowania technik reprodukcji (serigrafie czy serie tzw. transfer drawings). Z tego też powodu począwszy od lat 60. twórczość Rauschenberga coraz trudniej było nazwać malarstwem, wobec czego Douglas Crimp zaproponował jako bardziej adekwatne określenie „hybrydowa forma druku" (hybrid form of printing) ${ }^{24}$.

Począwszy od lat 60. odchodzenie od specyfiki medium dokonywało się także w obszarach sztuki konceptualnej, minimalizmu i sztuki zawłaszczania. Zmiany te zbiegły się z rozwojem filozofii poststrukturalizmu, poddającego krytyce metafizyczną opozycję wnętrza i zewnętrznego kontekstu oraz estetycznej autonomii, arbitralnie wyznaczonej ramą dzieła sztuki. Przede wszystkim jednak następowały one pod znakiem absolutnej dominacji fotografii, która niejako ze swojej natury sprzeciwia się idei autonomii medium. Rosalind Krauss odnosi to spostrzeżenie do twórczości fotokonceptualistów, którzy eksponując zależność fotografii od uzupełniającego ją podpisu, demonstrowali jej niezgodny z zasadą czystości medium charakter ${ }^{25}$. Praktyki fotokonceptualistów, a także analizowane przez Krauss prace Marcela Broodthaersa, Jamesa Colemana czy Williama Kentridge'a, obnażyły niedoskonałości właściwego modernizmowi redukcjonistycznego pojmowania medium, wskazując jednocześnie, że stawiają one także opór procesom kapitalistycz-

${ }^{21}$ Dostrzegając modernistyczny rodowód combines Rauschenberga, Barbara Rose pisała, że „powiększyły [one] do skali amerykańskiej collage Merz Schwittersa [...] z szerokim gestem de Kooninga”. B. Rose, Malarstwo amerykańskie XX wieku, tłum. H. Andrzejewska, Warszawa 1991, s. 114.

22 P. Piotrowski, W cieniu Duchampa. Notatki nowojorskie, Poznań 1996, s. 22-25.

${ }^{23}$ Armstrong, Painting Photography Painting, s. 130.

${ }^{24}$ D. Crimp, On the Museum's Ruins, „October” 1980, 13, s. 56.

${ }_{25}$ Krauss odwołuje się m.in. do prac takich artystów, jak Dan Graham, Robert Smithson, Douglas Huebler, Bernd i Hilla Becher, Allan Sekula czy Victor Burgin. Krauss, Reinventing the Medium, s. 294-295. 
nego przekształcania obrazu w towar. Dlatego Krauss zaproponowała przedefiniowanie kategorii specyfiki medium w „dyferencyjną specyfikę” (differential specifity $\left.\right|^{26}$. Odrzuca ona sprowadzanie medium do aspektu fizycznego i technologicznego (spopularyzowane przez szkołę Clementa Greenberga) ${ }^{27}$, co jednak nie oznacza porzucenia tego pojęcia w ogóle. Zakłada raczej jego problematyzowanie, rozpatrywanie całej jego złożoności, zmienności i zdolności do różnicowania się (self-differing) ${ }^{28}$. Tak pojmowane medium stanowi strukturę heterogeniczną, łączącą różne formy i przestrzenie ekspresji (np. sztukę wysoką z popularną lub fotografię i film z malarstwem).

Zestawienie twórczości Goldsteina i Wasowa wpisuje się w projekt „ocalenia" medium zaproponowany przez Krauss, ponieważ pozwala eksponować tę kategorię jako zdolną do różnicowania się dynamiczną i złożoną strukturę. Należy tu ponownie podkreślić właściwość polegającą na wzajemnych przesunięciach pomiędzy stosowanymi przez artystów mediami i przemieszczeniach w zakresie sposobów obrazowania między malarstwem i fotografią. O ile bowiem malarskie obrazy Jacka Goldsteina robią wszystko, by upodobnić się do (pozornie) „bezszwowej” natury fotografii, o tyle fotograficzne montaże Olivera Wasowa, imitując malarskie efekty, są jak gdyby wcieleniem piktorializmu w wydaniu Edwarda Steichena w epoce estetyki wideo i science fiction.

Goldstein, dążąc do maksymalnego odpersonalizowania stylistyki, zrzekł się wykonawstwa; jego prace, wytwarzane $z$ użyciem aerografu i narzędzi do precyzyjnego wykreślania linii, wykonali według jego projektów asystenci. Jeden $z$ nich, znany amerykański malarz Ashley Bickerton, wspominał, że zgodnie z założeniami Goldsteina, obrazy powstawały poprzez stopniowe nanoszenie jasnej farby akrylowej na czarne podłoże płótna ${ }^{29}$, co nasuwa kolejne

26 Zob. R. Krauss, „A Voyage on the North Sea”. Art in the Age of Post-medium Condition, New York 2000, s. 56.

${ }^{27}$ Jak zauważyła Krauss, modernistyczne sprowadzenie medium do aspektu materialnego wytworzyło fikcję, która zjednoczyła wszystkie warstwy dzieła w doskonałą całość. Co więcej, doprowadziło to do paradoksu, w którym „wojownicza redukcyjność modernizmu" stworzyła pojęcie malarstwa tak wąskie, że w rezultacie przekształciło się ono w swoje przeciwieństwo. Modernizm, sprowadzając kategorię medium do esencji, którą była płaskość, w istocie, niejako wbrew własnym intencjom, doprowadził do utożsamienia sztuki z obiektem. Tak z perspektywy czasu daje się odczytać narracja, dzięki której triumfowało malarstwo monochromatyczne (czy też minimalizm w ogóle), sprowadzając dzieło do jego fizycznego, materialnego wymiaru. Powierzchnia i podłoże obrazu stały się doskonałą jednością, a medium zredukowano do podłoża. Ibidem, s. 9-10, 53.

${ }^{28}$ Ibidem, s. 44.

29 A. Considine, Over the Rainbow with Jack Goldstein, „Art in America” [online], 20 listopada 2012, <http://www.artinamericamagazine.com/news-features/news/jackgoldstein-adam-lindemann/> [dostęp: 1 lutego 2017]. 
skojarzenie z procesem fotograficznym, gdzie z czerni negatywu wyłania się stopniowo światło obrazu. Z kolei Oliver Wasow w wywiadzie $z$ fotografką Daną Hoey przyznał, że najbardziej interesuje go fotografia, która dzieli pewne cechy z malarstwem, powstająca przy użyciu narzędzi i efektów naśladujących techniki malarskie. Paradoksalnie, uznając, że malarstwo wbrew wielu opiniom znajduje się w dobrej kondycji ${ }^{30}$, rozumiał je (i traktował) jako rodzaj fotograficznej postprodukcji, wtórnie wygenerowanej malarskości.

Zabiegi Goldsteina i Wasowa podważają kategorię specyfiki medium, nie unieważniając jednak pojęcia medium jako takiego. Definiują je jako zjawisko dynamiczne i oscylujące pomiędzy różnymi poziomami doświadczenia. Wskazują na jego obecność zarówno w aspekcie czysto technicznym (co na przykład u Wasowa objawia się jako rodzaj nostalgii za malarską konwencją ${ }^{31}$ ), jak i w wymiarze wirtualnym (jako nawiązanie do technologii optycznych lub transmisji telewizyjnych, generujących określone obrazy). Eksponują także medium jako określoną procedurę działania, podejmowania decyzji, które znajdują uzasadnienie w konceptualnym planie artysty. Wskazują wreszcie na medium jako przestrzeń, w której zachodzi projekcja obrazów przechowywanych w zasobie pamięci widza, stając się czymś w rodzaju odbicia jego niepokojów lub pragnień (fantazje na temat kosmicznych katastrof czy kontaktu z pozaziemską cywilizacją). Migoczący i niezdeterminowany charakter medium w swoim zawieszeniu pomiędzy materialnością i wirtualnością przypomina hologram, zjawisko jednoczesnej obecności i nieobecności oraz równoległego znajdowania się w różnych układach przestrzennych (właściwość hologramu podkreślał Douglas Crimp między innymi w opisach performance'ów Goldsteina, o których będzie mowa niżej/32.

\section{OBRAZY PAMIĘCIOWE}

Analogie między pracami obu amerykańskich artystów objawiają się także w ich potencjale semantycznym, który, jak sądzę (i chciałbym to przypuszczenie podkreślić), został świadomie ograniczony do niemal tautologicz-

30 D. Hoey, Interview with Oliver Wasow [online], <http://carlosmotta.com/artwurl/ interviews/INT020.html> [dostęp: 1 lutego 2017].

${ }^{31}$ Nasuwa się tu analogia z opisywaną przez Krauss praktyką artystyczną Jeffa Walla, który w swoich wielkoformatowych fotografiach nawiązuje do malarskich wzorców romantyzmu i modernizmu. Należy jednak podkreślić, że Krauss - w odróżnieniu od innych interpretatorów twórczości Walla - w jego konkretnym przypadku widzi nie tyle próbę redefinicji medium i wyzyskania jego złożonego charakteru, ile jedynie częsty w sztuce lat 80. pastisz dawnej konwencji. Krauss, Reinventing the Medium, s. 297.

32 Crimp, The Photographic Activity..., s. 92-94. 
nych relacji między znaczonym i znaczącym. Nieokreślony i wewnętrznie zróżnicowany status medium w tym zredukowaniu znaczenia do odległego echa bądź czegoś w rodzaju powidoku odgrywa zasadniczą rolę. Zagadnienie, które wyłania się w tym miejscu, dotyczy sposobu, w jaki prace Goldsteina i Wasowa wykorzystują mechanizm kojarzenia zapośredniczonych obrazów funkcjonujących w pamięci. Wymaga to odniesienia się do językoznawczej kategorii związków syntagmatycznych.

W tym kontekście trzeba podkreślić, że powstające w latach 80. obrazy Jacka Goldsteina stanowiły kontynuację działań podejmowanych przez niego we wcześniejszym etapie twórczości. Krótkie filmy zrealizowane na taśmie 16 mm, jak The Knife, Shane (1975), The Jump (1978), czy performance Two Fencers (po raz pierwszy zaprezentowany w roku 1976) łączy technika polegająca na wyizolowaniu obrazu z tła i usunięciu wszelkich elementów, nawiązujących do określonego kontekstu. Na przykład w trwającym dziewiętnaście sekund filmie Jump przedstawiony został skoczek dokonujący skoku $z$ trampoliny do basenu. Obraz poddany obróbce metodą animacji rotoskopowej (polegającej na zamianie filmu aktorskiego w animowany, przez ręczne przerysowywanie kolejnych klatek ${ }^{33}$, ukazuje jednak tylko sylwetkę skaczącej postaci na jednorodnym czarnym tle. Figura skoczka połyskuje intensywną czerwoną poświatą, mieniącą się gdzieniegdzie brokatowym blaskiem. Ta sama poświata obecna była w performance Two Fencers, w trakcie którego dwóch szermierzy, oświetlonych punktowo czerwonymi reflektorami, toczyło walkę na scenie oddalonej o kilkanaście metrów od widowni ${ }^{34}$. Jak pisał Douglas Crimp, podstawowy efekt, w obu przypadkach uzyskany przez zastosowanie czerwonej poświaty i wtopienie postaci w ciemne tło, polegał na ustanowieniu dystansu między widzem a oglądanym wydarzeniem, co z kolei umożliwiło badanie warunków postrzegania i percepcyjnych przyzwyczajeń. Stawką eksperymentów Goldsteina było ukazanie reprezentacji jako struktury znaczącej, lecz nie za sprawą związku ze swoim desygnatem, tylko dzięki ustanowieniu relacji z innymi reprezentacjami ${ }^{35}$. Obraz, uwalniając się od skojarzenia $z$ przedmiotem odniesienia, poszukuje jednocześnie związków z obrazami przechowywanymi w pamięci widza, które stopniowo go zastępują. W ten sposób dokonała się na przykład transformacja obrazu sportowców uprawiających szermierkę (wspomagana odpowiednią muzyką) w scenę

${ }^{33}$ Crimp, Pictures, s. 17.

${ }^{34}$ Należy dodać, że pokazowi towarzyszyła muzyka naśladująca ścieżki dźwiękowe do filmów płaszcza i szpady. Kiedy po pewnym czasie zainscenizowana została śmierć jednego z szermierzy, światła zgasły, lecz muzyka brzmiała nadal. Ibidem, s. 20.

35 Ibidem, s. 17, 19. 
walczących muszkieterów z filmu przygodowego. Jest to mechanizm, który Crimp porównał do językoznawczego rozróżnienia opisanego przez Ferdinanda de Saussure'a na związki pomiędzy elementami wypowiedzi, przyjmującymi charakter syntagmatyczny lub asocjacyjny ${ }^{36}$. Związki syntagmatyczne polegają na następstwie sąsiadujących ze sobą elementów (wyrazów w zdaniu) w określonym, rzeczywistym szeregu, a wartość poszczególnych elementów wynika $z$ różnicy pomiędzy elementami je poprzedzającymi lub po nich następującymi. Związki asocjacyjne nie mają charakteru liniowego następstwa, lecz polegają na mnemonicznych skojarzeniach z elementami nieobecnymi w szeregu. Mają one zatem zdolność łączenia elementów niewystępujących w jednej wypowiedzi, ograniczoną jedynie indywidualnymi predyspozycjami i kulturowym wtajemniczeniem ${ }^{37}$. Taki właśnie charakter, według Crimpa, mają filmowe sekwencje Goldsteina, w których poszczególne obrazy - pozbawione czytelnych związków syntagmatycznych - dążą do łączenia się w mnemoniczne asocjacje ${ }^{38}$.

Wydaje się, że tę charakterystykę można odnieść też do obrazów Goldsteina i fotografii Wasowa. Wprawdzie bezosobowa, zdystansowana formuła ukazywania zjawisk na jednorodnym ciemnym tle w pierwszym przypadku i powtarzalny zestaw zabiegów postprodukcyinych w drugim czynią z nich spójne stylistycznie serie, lecz ich siła oddziaływania polega na pozostawaniu poszczególnych prac w ścisłej relacji z obrazami przechowywanymi w pamięci widza, będącymi na ogół efektem doświadczenia zapośredniczonego technologicznie (dzięki technologiom transmisji obrazu).

Prace Goldsteina przedstawiają zjawiska znane dzięki mniej lub bardziej zaawansowanej technologii (takiej jak fotografia czy radioastronomia) ${ }^{39}$, automatycznie wiążąc się ze sobą jako obrazy nienależące do sfery osobistego doświadczenia i znane jedynie jako reprezentacja. Jednocześnie, niezależnie

36 Ibidem, s. 20.

37 Zob. F. de Saussure, Kurs językoznawstwa ogólnego, tłum. K. Kasprzyk, Warszawa 1961, s. 131-134.

38 Crimp, Pictures, s. 20.

39 Jean-François Lyotard w eseju poświęconym francuskiemu malarzowi Jacques'owi Monory, po części również zainteresowanemu w swojej twórczości tematyką „astronomiczną", dowodził, że wiedza osiągana w imię współczesnego eksperymentowania nie należy do nas, lecz jest własnością nowych technologii. Tworząc kategorię „wzniosłej immanencji” (jej odpowiednikiem u Jamesona byłaby „technologiczna wzniosłość”), pytał: „Czyż jesteśmy w stanie doświadczyć pierścieni Saturna? Najbardziej odległej novae? Galaktyk oddalających się z pełną prędkością w przeciwległe kąty wszechświata?" J-F. Lyotard, The Assassination of Experience by Painting - Monory / L'assassinat de l'expérience par la peinture - Monory, red. S. Wilson, London 1998, s. 226. 
od tego, że prezentują zjawiska tak różnorodne, jak zarejestrowane przez radioteleskop kosmiczne eksplozje, nocna panorama miasta rozświetlonego intensywnymi rozbłyskami, gwałtowne wyładowania elektryczne czy wizerunek wybuchającego wulkanu, mają cechę wspólną, którą jest zatrzymana w kadrze gwałtowność i intensywność wydarzenia ${ }^{40}$. Buduje to subtelną semantyczną relację między tym, co kojarzone $z$ technologią, a przeczuciem katastrofy. Co jednak ważne, relacja ta pozbawiona jest dosłowności. Nie jest to znaczenie obrazu, lecz dyskretne, milczące przeczucie, któremu towarzyszy świadomość przestrzennego dystansu wobec obserwowanych zjawisk. Podobny proces zachodzi w fotografiach Wasowa, prezentujących wizje science fiction znane $z$ kina i telewizji. Ich oddziaływanie opiera się na skojarzeniu obrazu z technologią przeznaczoną do produkcji fikcji, która ostatecznie rości sobie prawo do prawdy. Prace te pozostawiają widza w stanie biernego oczekiwania na coś, co rzekomo nastąpi, choć nie jest to przeczucie odległej katastrofy, jak w przypadku obrazów Goldsteina. Chodzi tu raczej o świadomość nieuchronności tego, co ukazane, a także o podobne do wywoływanego przez transmisje obrazu telewizyjnego wrażenie jednoczesnej ekscytacji i melancholii. Prace Wasowa nie znaczą nic ponad to, choć należałoby powiedzieć, że nie znaczą prawie nic, zaledwie muskając znaczenie po powierzchni.

\section{WZNIOSEY SPEKTAKL}

Widowiskowość prac Goldsteina, ale także Roberta Longo czy Troya Brauntucha, Hal Foster traktował jako zjawisko typowe dla późnego kapitalizmu, transformującego przedmioty, zdarzenia i ludzi w obrazy gotowe do konsumpcji ${ }^{41}$. W książce Recodings. Art, Spectacle and Cultural Politics, konfrontując słynne spostrzeżenia Guy Deborda ${ }^{42} z$ malarstwem i performance'ami

${ }^{40}$ Co ciekawe, jednocześnie uderza ich niezwykła, oparta na symetrii statyka. Dotyczy to zwłaszcza malarskich symulacji widoków z radioteleskopu.

${ }^{41}$ H. Foster, Powrót Realnego. Awangarda u schyłku XX wieku, tłum. M. Borowski, M. Sugiera, Kraków 2010, s. 115.

42 Debord pisał między innymi: „Spektakl jako nieodzowne upiększenie produkowanych towarów, jako ogólna wykładnia racjonalności systemu i jako nowoczesny sektor gospodarczy, który bezpośrednio wytwarza coraz większą liczbę obrazów-przedmiotów - to czołowy produkt obecnego społeczeństwa". Spektakl opiera się więc na właściwej kapitalizmowi fetyszyzacji rzeczy i ich zamiany w towar, ale jednocześnie, „spektakl to k a p i tał, który osiągnął taki stopień akumulacji, że stał się obrazem”. „Jego zadanie, zauważył też Debord, polega na u ka zywa ni u, za pomocą rozmaitych specjalistycznych zapośredniczeń, świata niedającego się już uchwycić bezpośrednio - przyznaje [...] pierwszeństwo zmysłowi wzroku" (Debord, Społeczeństwo spektaklu..., s. 37, 38, 44). O tym, 
Roberta Longo z przełomu lat 70. i 80., krytyk zwrócił uwagę, że prace te demonstrują zasadę działania spektaklu: nie są one reprezentacją, działającą dzięki wierze w realizm, lecz opierają się na naszej fascynacji tym, co hiperrealne; są „perfekcyinymi” obrazami, które sprawiają, że ulegamy złudzeniu i całkowicie się mu poddajemy ${ }^{43}$. Obrazy te porzuciły tradycyjną referencyjność na rzecz symulacji, ponieważ tylko w taki sposób są w stanie zobrazować przepełnioną schizofreniczną mieszaniną niepokoju i euforii współczesną rzeczywistość. Symulacja, jak pisał Foster, przeciwstawia się reprezentacji, o ile bowiem podstawową zasadą reprezentacji jest ekwiwalencja między znakami i realnością, o tyle w symulacji znaki wyprzedzają realność, nie odnosząc się do niej, lecz poddając ją jedynie zabiegom estetyzacji ${ }^{44}$. Podporządkowujemy się logice spektaklu, właśnie wobec owej utraty realności, bądź - jak pisał Jean Baudrillard - utraty przedmiotów odniesienia, ale także dlatego, że spektakl dostarcza fetyszystycznych obrazów, które utracie zaprzeczają lub też ją rekompensuiąa ${ }^{45}$.

Zjawisko to prezentuje się jeszcze dobitniej w kontekście rozwoju technologii transmisji obrazu, w który wpisują się przedstawienia Jacka Goldsteina i Olivera Wasowa. Powstały one bowiem w czasie, gdy swoją dominującą pozycję w kulturze lat 80 . ugruntowała telewizja, a komputery rozpoczynały swój marsz do dzisiejszej hegemonii. Jak pisał Jameson, urządzenia te stawiały całkiem nowe wymagania estetyczne, tworząc nie tyle „mimetyczną idolatrię”, ile narracje opowiadające o procesach reprodukcji, „wypełnione kamerami filmowymi, odtwarzaczami wideo, magnetofonami, słowem: technologią produkcji symulakrum" ${ }^{46}$. Tak też - jako reprezentacje wywodzące się z estetyki telewizji - jawią się przesycone niepokojącymi, fosforyzującymi barwami fotografie Olivera Wasowa z cyklu Hover. „Telewizyjna” proweniencja fotografii wiąże się nie tylko $z$ tematyką inspirowaną programami, serialami i filmami science fiction, ale również, a może przede wszystkim, z reprodukowaniem efektów niedoskonałości obrazu telewizyjnego - jak szum, silny kontrast czy ograniczony zakres przejść tonalnych. Efekty te są pozbawionymi odniesienia znakami, stanowiącymi element estetyzacji obrazu, choć war-

\footnotetext{
że sztuka stała się obszarem reprodukowania spektakularnych efektów, obrazów i znaków, Foster pisał w odniesieniu do twórczości tamtej dekady, Fredric Jameson natomiast nadał temu zjawisku charakter uniwersalnej zasady postmodernizmu (Jameson, Postmodernizm, czyli logika kulturowa..., s. 35-36 i inne).

${ }^{43}$ H. Foster, Recodings. Art, Spectacle, Cultural Politics, Seattle, Washington, 1985, s. 83. Zob. też: Debord, Społeczeństwo spektaklu...

${ }^{44}$ Ibidem, s. 90.

45 Foster, Recodings. Art, Spectacle..., s. 83.

46 Jameson, Postmodernizm, czyli logika kulturowa..., s. 36.
} 
to dodać, że pełnią też rolę ideologiczną, uwiarygodniając przekaz oparty na spekulacjach, przypuszczeniach i fantastycznych hipotezach (opierają się na sugestii, że wydarzenie miało niespodziewany i krótkotrwały charakter, dlatego obraz jest niewyraźny) ${ }^{47}$. Niezależnie od tego, prace Wasowa (a po części także Goldsteina), jako „perfekcyjne” i hiperrealne obrazy wpisują się w zapoczątkowany przez telewizję lat 80. nowy etap kapitalistycznego procesu akumulacji dóbr, w którym zdematerializowane towary sprowadzone zostały do strumienia znaków. O ile bowiem wcześniej telewizja rozumiana była jako odrębne, specyficzne medium, wytwarzające oparte na reprezentacji określone pole semantyczne, o tyle w latach 80 . stała się jedynie systemem dystrybucji danych - wizualnych i narracyjnych jednostek, zestawianych w dowolne sekwencje, tworzące abstrakcyjny przepływ obrazów pozbawionych znaczenia, w których nie obowiązują mechanizmy społecznej racjonalizacji ${ }^{48}$. Stanowiące dopełnienie tej diagnozy słowa Jeana Baudrillarda, że „telewizja jest wizualnym przekazem $z$ innego świata, nieadresowanym w gruncie rzeczy do nikogo, złożonym z uwalnianych beznamiętnie obrazków, obojętnym na zawarte w nich przesłanie" ${ }^{\prime 4}$, mogłoby zatem odnosić się także do prac Wasowa.

Interpretacja ta, przedstawiając prace Goldsteina i Wasowa jedynie w kategoriach kompulsywnego mechanizmu produkowania symulakrów, nie tylko stawia pod znakiem zapytania ich krytyczny potencjał, ale zdecydowanie

47 Zakłócenia obrazu mogą też potęgować szokujący wymiar przedstawienia. Jak zauważył Hal Foster, powielane w sitodrukach Warhola z serii Death in America skazy fotografii, na podstawie których powstały (przesunięcia, rozmazania, wybielenia, naddarcia, wyblaknięcia), stanowią punctum (umiejscowione nie w temacie, lecz przybierające właśnie postać zakłóceń); są „wizualnymi ekwiwalentami naszych przegapionych spotkań z Realnym". Foster, Powrót Realnego, s. 162.

${ }^{48}$ J. Crary, Eclipse of the Spectacle, w: Art After Modernism: Rethinking Representation, red. B. Wallis, New York, Boston 1985, s. 284-289, 291. Jako wczesny przejaw tego zjawiska autor wskazuje też na książkę wspomnianego J.G. Ballarda, The Atrocity Exhibition z roku 1969, stanowiącą zbiór luźno powiązanych ze sobą nowel, opisujących doświadczenie życia w nowoczesnym mieście, którym czytelność odbiera nadmiar detali i wątków oraz brak narracyjnej struktury. Książka jest literackim odpowiednikiem dokonanej przez telewizję w latach 80. „anihilacji pola semantycznego” (s. 291-292).

${ }^{49}$ J. Baudrillard, Ameryka, tłum. R. Lis, Warszawa 2011, s. 62. Spostrzeżenie Baudrillarda pokrywa się z kolei z rozpatrywaniem telewizji jako heterotopii, w odwołaniu do terminu wprowadzonego przez Michela Foucaulta, oznaczającego inne, alternatywne miejsce, rodzaj „efektywnie odgrywanej utopii, w której wszystkie inne rzeczywiste miejsca, jakie można znaleźć w ramach kultury, są jednocześnie reprezentowane, kontestowane i odwracane". Charakterystyczne dla heterotopii jest połączenie miejsc, zjawisk i porządków czasowych wzajemnie sobie obcych. M. Foucault, Inne przestrzenie, tłum. A. Rejniak-Majewska, „Teksty Drugie” 2015, 6, s. 117-125. 
mu przeczy. Ostatecznie, jak pisał Hal Foster, estetyka reprezentowana między innymi przez obrazy Goldsteina okazała się niezdolna bądź niechętna rzuceniu wyzwania konsumpcyinemu uprzedmiotowieniu i zamieniła się $\mathrm{W}$ „mieszankę politycznej rezygnacji i fetyszystycznej fascynacji” 50 .

Tymczasem warto przyjrzeć się pewnemu aspektowi spektaklu, właściwemu wielu przykładom sztuki lat 80., jakim jest wzniosłość, na który zwraca uwagę także Foster w Recodings. Naświetlenie tego wątku nie łagodzi wprawdzie nieprzychylnej oceny wystawionej przez krytyka „widowiskowej” i „fetyszystycznej" sztuce lat 80., ale daje szansę przedstawienia prac Goldsteina i Wasowa w nieco bardziej złożonym i rozproszonym świetle, gdzie kwestie produkcji symulakrów okażą się czymś więcej niż tylko pustym gestem. Wzniosły spektakl wykorzystuje mechanizmy rozpoznane przez psychoanalizę, według których utrata realności (lub też przedmiotów odniesienia), jakiej doświadczamy we współczesnej kulturze, domaga się rekompensaty, substytutu, który złagodzi owo traumatyczne doświadczenie. W ten sposób tworzymy fetysz, na ogół pochodzący z ostatniego okresu poprzedzającego stratę $e^{51}$. Tym okresem - jak zauważył Foster, przywołując słowa Baudrillarda - może być faszyzm, który wobec jednowymiarowości współczesnej kultury podejmował fanatyczne wysiłki reanimacji „reprezentacji atawistycznych”, ucieleśniających realność, jak natura, mit, rasa, imperium ${ }^{52}$. Amerykański krytyk, odnosząc się do cyklu performance'ów Roberta Longo z przełomu lat 70. i 80., stwierdził, że artyści sięgają po tego typu "autorytarną" estetykę, ponieważ ona właśnie ilustruje fundamentalne zasady współczesnego spektaklu, pozwalając dostrzec zarówno właściwy mu wysiłek przywrócenia realności, jak i sposoby manipulowania odczuciem jej utraty ${ }^{53}$. W multimedialnym performance Sound Distance of a Good Man z roku 1977 Longo śledził nasze próby kompensacji straty, odbywające się z pomocą archaicznych obrazów i form. Sprowadzając składające się na dzieło elementy tańca, muzyki, śpiewu operowego, rzeźby i filmu do zestawu efektów, noszących znamię nieustającej kulminacji (np. dramatyczne oświetlenie i wzniosłe pozy skontrastowane $z$ agresywnym, wojowniczym rytmem), pozbawił je także narracyjnej bazy. W ten sposób - jak pisał Foster - wykreowane zostało jednoczesne poczucie aliena-

${ }^{50}$ Foster, Powrót Realnego..., s. 115.

${ }^{51}$ Foster, Recodings. Art, Spectacle..., s. 79. Zob. też J. Baudrillard, Symulakry i symulacja, tłum. S. Królak, Warszawa 2005, s. 58-59.

52 Foster, Recodings. Art, Spectacle..., s. 80. Pierwszych uwag na temat estetyzacji rzeczywistości (np. wojny) w faszyzmie należy szukać oczywiście u Waltera Benjamina. Zob. Benjamin, Dzieło sztuki..., s. 93-95.

${ }^{53}$ Foster, Recodings. Art, Spectacle..., s. 81. 
cji i fascynacji, co stanowi istotę działania spektaklu ${ }^{54}$. Performance Longo, redukując obraz do spektakularnych efektów pozbawionych swojego źródła, ustawia odbiorcę w pasywnej pozycji marzyciela, widza wzniosłego widowiska i konsumenta zarazem ${ }^{55}$. Wydaje się, że w tych manipulacjach tkwi istota krytycznego zamysłu Longo. Jego performance, operując wzniosłymi obrazami, odwołują się do strachu widzów przed nieobecnością władzy i jej autorytetu. Tym samym demonstrują mechanizm przejęcia przez spektakl kontroli nad widzami, polegający na rozpoznaniu ich pragnień oraz taktyce, która zakłada romantyczne uwiedzenie przy jednoczesnym autorytarnym przymusie uległości ${ }^{56}$.

Lektura wspomnień Lorne Lanninga ${ }^{57}$ - byłego asystenta Jacka Goldsteina, należącego do zespołu wykonawców jego obrazów z lat 80. - dostarcza wielu argumentów wskazujących, że jego fascynacje kierowały się w stronę autorytarnej władzy spektaklu, ogniskując się wokół wzniosłości, doskonałości i dostojności. Lanning wspominał między innymi, że Goldstein, chcąc pokazywać rzeczy, których nie jesteśmy w stanie zobaczyć gołym okiem, pragnął zarazem wznieść swoje obrazy do poziomu technicznej perfekcji, niemożliwej do osiągnięcia przez człowieka. Ambicje Goldsteina prezentują się w szczególny sposób w kontekście uwagi Lanninga, że był on zafascynowany ideą monolitu z filmu 2001: Odyseja kosmiczna Stanleya Kubricka ${ }^{58}$ - wykonanego przez pozaziemską inteligencję czarnego prostopadłościanu, będącego źródłem wszelkiej wie$\mathrm{dzy}$ i kontrolującego los ziemskiej cywilizacji. Monolit charakteryzował się idealną strukturą, pozbawioną jakichkolwiek śladów wykonania, znajdującą się zarówno poza możliwościami ludzkiego rzemiosła, jak i sił natury.

Obrazy Goldsteina, zwłaszcza te, które przedstawiają zjawiska kosmiczne, reprezentują tę samą, milczącą wzniosłość monolitu, jednoczącego pojęcia władzy i wiedzy, znajdującego się poza kategoriami kultury i natury. Wzniosłość ta przejawia się w spektakularnych efektach, uwodzicielskich dzięki rozpoznaniu naszego pragnienia porządku i symetrii, stworzyła ją zaś ściśle przestrzegana precyzja wykonania. W tym sensie obrazy te działają podobnie jak analizowane przez Hala Fostera prace Roberta Longo - obnażając mechanizm przejmowania przez spektakl kontroli nad widzem bądź też wskazując nasze, czułe na uwodzicielską siłę widowiska, punkty (tak też można inter-

${ }^{54}$ Ibidem.

55 Ibidem, s. 82 .

${ }^{56}$ Ibidem.

57 M. Connor, Jack Goldstein, Glitch Artist? An Interview with Lorne Lanning, „Rhizome" [online], 21 maja 2013, <http://rhizome.org/editorial/2013/may/21/jack-goldsteinglitch-artist/> [dostęp: 5 maja 2017].

${ }^{58}$ Ibidem. 
pretować prace Olivera Wasowa, odwołujące się do fantazji na temat spotkania z przybywającą z kosmosu siłą, dysponującą wzniosłą technologią i podporządkowującą sobie nasz świat).

Jednak autorytarna siła perfekcyjnego wizerunku - symetrycznego, statycznego, monumentalnego i pozbawionego śladów wykonania - obnaża nie tylko potrzebę widza, by być uwiedzionym i podporządkowanym w ramach spektaklu. Goldstein, który w swoich obrazach zaadaptował surowość i rygory konceptualizmu, siłę porządku przeciwstawiał chaosowi dominującego w sztuce lat 80. neoekspresjonizmu. Jak wspomina Lanning, celem, który wyznaczył sobie artysta, była ucieczka od „malarstwa typu Cro-Magnon”, jak nazywał surowy ekspresjonizm Juliana Schnabla czy stłoczone figuracje Davida Salle' $\mathrm{a}^{59}$. W tym świetle autorytarna wzniosłość, wyrażająca się przez rygor i dyscyplinę, skierowana została wprost przeciwko tendencjom artystycznym opierającym się na spontaniczności, przypadkowości i subiektywizmie.

Nawet jeśli powyższe uwagi pozwalają ocalić krytyczny potencjał spektakularnych reprezentacji Goldsteina i Wasowa, to warto podkreślić, że nie wyklucza to ich komercyinego sukcesu. O ile bowiem spostrzeżenia Davida Salle'a zawarte w eseju poświęconym postaci Goldsteina, że sprowadził on formalny rygor swoich obrazów do poziomu efektownego stylu, wydają się zbyt powierzchowne, o tyle znamienne jest, że w ostatnich latach (zwłaszcza po prezentującej całość jego dorobku artystycznego wystawie „Jack Goldstein x 10 000” w nowojorskim Jewish Museum w roku 2013) zostały ponownie odkryte jako chic décor ${ }^{60}$.

Na zakończenie należy jednak podkreślić, że obrona krytycznego charakteru prac Goldsteina i Wasowa możliwa jest tylko w przestrzeni wymiany, w której między obrazami i fotografiami, a także w obrębie ich własnej struktury, zachodzi proces różnicującego przenikania się mediów. W przestrzeni, w której współobecne są różne wcielenia i formy obecności medium, a fotografia i malarstwo wymieniają się sposobami ekspresji i technikami obrazowania, ujawniają się wielopoziomowe relacje prac amerykańskich artystów z rozmaitymi innymi formami reprezentacji. Odwołując się do obrazów wirtualnych, wygenerowanych przez urządzenia optyczne lub techniki transmisji telewizyinej, artyści ci unikali związków z modernistyczną ikonografią, ponieważ istotą ich projektu jest podejmowanie kwestii referencji, czyli badanie obrazu jako takiego, oczyszczonego zarówno z modernistycznej tradycji, jak i z treściowych związków. W przestrzeni medialnej wymiany dokonuje się

59 Ibidem.

${ }^{60}$ D. Salle, How to See. Looking, Talking, and Thinking about Art, New York, London 2016, s. 154-155. 
zatem istotna zmiana w definiowaniu reprezentacji. Jak pisał Douglas Crimp, reprezentacja nadal pozostaje nieodzownym elementem naszej zdolności pojmowania świata, lecz już nie - jak w sztuce modernistycznej - dzięki temu, do czego się odnosi (w przypadku prac Goldsteina i Wasowa przedmiot odniesienia znajduje się poza możliwościami naszego bezpośredniego doświadczenia lub nie istnieje), a dzięki nawiązaniu relacji $z$ innymi reprezentacjami ${ }^{61}$, na przykład obrazami zapośredniczonymi lub pamięciowymi. Niepewny i zróźnicowany charakter medium, objawiający się w sposobie realizacji obrazów i fotografii, prowokuje więc pytania o ontologiczny status reprezentacji, zawieszony pomiędzy materialnością i wirtualnością, obecnością i nieobecnością, bliskością i dystansem. Tymczasem sprowadzenie ich jedynie do atrakcyjnego, dekoracyjnego towaru jest $\mathrm{w}$ istocie powrotem do modernistycznego redukcjonizmu, w świetle którego tracą one na krytycznej wymowie, choć oczywiście mogą zyskać na wartości rynkowej, stając się chic décor. Taka perspektywa równoznaczna jest ze zniesieniem wielowymiarowości całego projektu; usuwa z pola widzenia szereg kontekstów, sprawiając, że nikną one pod powierzchnią estetycznego powabu.

Oczywiście przykłady Goldsteina i Wasowa nie są odosobnionymi przypadkami ambiwalencji pomiędzy krytycznym potencjałem a towarowym obliczem sztuki końca XX wieku. Hal Foster w tym kontekście analizował między innymi niejasny status geometrycznej neoawangardy (tzw. neo-geo) „podejmującej temat percepcji” i sprowadzającej jednocześnie abstrakcję do dizajnu czy dzieła Jeffa Koonsa i Haima Steinbacha, eksponujące konsumpcyjną wartość sztuki, czyniąc z niej luksusowy towar ${ }^{62}$. O tym, że granica między krytyką a współudziałem jest płynna i podlega niepostrzeżonym przemieszczeniom, w ciekawy sposób świadczą słowa artysty i krytyka sztuki Thomasa Lawsona, odnoszące się zresztą do malarstwa Davida Salle'a. Praktykę korzystania przez malarza z niezliczonych cytatów i parafraz z rozmai-

${ }^{61}$ Crimp, Pictures, s. 19.

${ }^{62}$ Kulturowe źródła ambiwalencji między postawą krytyczną a współudziałem Foster znajduje w wieku XIX, powołując się na opisy francuskiej bohemy w epoce II Republiki w 18 brumaire'a Ludwika Bonapartego Karola Marksa czy wizerunek Charlesa Baudelaire'a jako „tajnego agenta własnej klasy”, który wyłania się z lektury eseju Paryż II Cesarstwa według Baudelaire’a Waltera Benjamina. Odwołuje się także do stworzonej przez niemieckiego filozofa Petera Sloterdijka kategorii cynicznego rozumu, opisującej charakter współczesnej kultury. W Krytyce cynicznego rozumu Sloterdijk definiuje ją jako dwuznaczną postawę, polegającą na świadomości fałszywych treści stojących za ideologią, przy jednoczesnej ich biernej akceptacji, nazywając ją „oświeconą fałszywą świadomością". Zob. Foster, Powrót Realnego..., s. 139-151; P. Sloterdijk, Krytyka cynicznego rozumu, tłum. P. Dehnel, Wrocław 2008, s. 20-24 i inne. 
tych mediów Lawson nazwał strategią infiltracji i sabotażu. Wskazał jednak, że strategia ta jest obarczona ryzykiem, przypominającym sytuację uwodziciela, który pierwotnie miał tylko uwieść swoją ofiarę, a ostatecznie się w niej zakochał ${ }^{63}$.

Filip Pręowski

Wydział Sztuk Pięknych

Uniwersytet Mikołaja Kopernika, Toruń

IN SPACE OF EXCHANGE.

JACK GOLDSTEIN'S PAINTINGS AND OLIVER WASOW'S PHOTOS

\section{Summary}

The paper, focused on the works of two American artists of the 1980s, Jack Goldstein and Oliver Wasow, is an attempt to consider the process of crossing boundaries between two different kinds of art. That phenomenon was a characteristic feature of the late twentieth-century art, including also The Pictures Generation to which both artists actually belonged. Both Goldstein, in his paintings from the 1980s, and Wasow, in his photos from the same period, used mediated images and simulated the effects achieved by the advanced technology of nature watching and picture transmission. In consequence, among several features common to the works under scrutiny, one realizes in the first place a significant change in the defining of the medium understood not just as a material and technological aspect of the work, but as a dynamic and complex structure connecting different forms and spaces of artistic expression with the spectator's experience. Challenging the autonomy of art and the separate identities of its kinds, rooted in the historical avant-garde, leads to a revision of the modernist idea of the medium, as well as to reconsidering the ways in which its changing status influences the semantic potential of paintings and photos. Moreover, the spectacular paintings of Goldstein and photos by Wasow, made and taken in relation to the rapidly changing technology of image transmission, provokes questions about their critical potential: do they denounce the spectacle-making techniques or, as fetishized merchandise, do they just take part in it? The frame of reference are analyses conducted by American critics and art historians who redefined the concept of the medium in contemporary artistic practices, examined the role of photography, and considered the subjection of the late twentieth-century art to the logic of spectacle, such as Rosalind Krauss, Douglas Crimp, and Hal Foster.

Keywords:

Goldstein Jack (1945-2003), Wasow Oliver (1960-), painting, photography, medium, mediated image, memory image, simulation, spectacle

${ }^{63}$ T. Lawson, Last Exit: Painting, w: Painting. Documents of Contemporary Art, s. 33. 